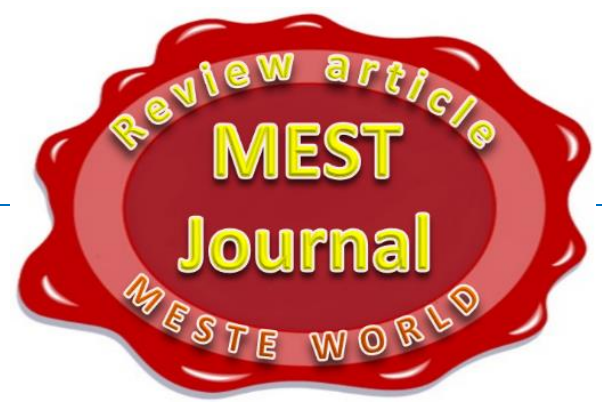

\title{
GREEN GROWTH AND POSSIBILITIES OF ITS ENSURING
}

\author{
Eva Romančiková \\ School of Economics and Management in Public Administration in Bratislava, Bratislava, \\ Slovakia
}

() MESTE NGO

JEL category: F43, 01, 04

\begin{abstract}
The article identifies selected environmental aspects of ensuring green growth, which are being significantly affected by the ongoing globalisation process and subsequent economic growth accompanied by international trade liberalisation and movement of capital and investments in transforming economies. They represent positive and negative effects, whose extent can be significantly affected by structural changes, environmental policy of state and transnational environmental regulation. In Europe 2020 strategy, the European Union specifies green growth factors whose implementation presupposes the adoption of particular measures at the level of the European Union itself as well as within national economies, aiming at environmental burden reduction. It predominantly concerns the solution of economic growth in relation to its material and energetic demands, structural changes execution as well as the adoption of efficient legislation regarding environmental protection. In this relation, production innovations, changes to implemented technologies and substitutions of production inputs are gaining importance. Increased legislative effectiveness presupposes an increase of economic and environmental efficiency of implemented economic tools, aiming at the strengthening of stimulus and fiscal functions of public finance.
\end{abstract}

Keywwords: environment, environmental policy, positive and negative effects of the globalisation process, environmental policy tools, transnational regulation

\section{INTRODUCTION}

Present time is characterised by a state when the $\mathrm{EU}$, in an effort to eliminate the effects of economic crisis and create conditions for effective economic growth of the EU, has adopted "Europe 2020" strategy for the upcoming decade. The strategy specifies growth factors, ensuring of which presupposes the adoption of particular

Address of the author:

Eva Romančiková

䟩" eva.romancikova@vsemvs.sk measures at the EU level as well as by national economies. They are the following growth factors:

- Smart growth, whose implementation presupposes economic development based on:

- innovations,

- knowledge (education, training), digitisation of society.

- Green growth, whose implementation presupposes minimisation of the burden on environment by means of: 
- more extensive usage of renewable energy resources,

- increasing energy efficiency (reduced energy consumption),

- decreasing the generation of greenhouse gas emissions.

- Inclusive growth is related to the need of solving the issues of social and territorial cohesion. It is necessary in this relation to draw increased attention to the following issues:

- employment,

- knowledge and skills

- fight against poverty.

The objectives of green growth ensuring are:

- reduction of greenhouse gas emissions by $20 \%$ compared to the level reached in 1990 ,

- increase of renewable resources share in the final energy consumption by $20 \%$,

- increase of energetic effectiveness by $20 \%$.

Objectives related to the greenhouse gas emissions reduction by $20 \%$ of the level recorded in 1990, falling under the emission trading system, are ensured by means of allocating emission quotas by the EU. The fulfilment of emission reduction objectives out of sectors without allocated emission quotas has been promising for Slovakia. Slovakia even has unused room, and can thus increase emissions by $13 \%$ in these sectors.

The objective in the sphere of increasing renewable resources share in final energy consumption at $20 \%$ seems to be accomplishable for the EU. However, Slovakia only fulfils this objective for 14\%. Energy effectiveness increase by $20 \%$ will be demanding for Slovakia. The given priorities are mutually closely interrelated and their solution according to Commission's intentions will enable the EU to achieve a $2 \%$ annual GDP growth in 2020, and create 5.6 million new jobs (European Commission, 2010)

A precondition of achieving these objectives is the reflection of these intentions in the economic policies of states and their partial sector policies, including environmental policy. Closer interconnection of the aforementioned policies can cause shifts in the understanding of economic growth as a growth characterised by economic indicators and welfare aimed at green growth, implicitly including economic, social and environmental aspects.

It means that it is necessary in decision-making processes at each management level to reflect, besides other influences, also the bearability of environmental burden and economic consequences arising in case of environmental damage. A crucial phase of the implementation of this process is the identification of factors opening room for deterioration of the quality of environment. These factors include:

- economic growth and its material and energy demandingness. Increased economic activity in a country can but does not have to have an impact on the quality of environment. Positive effects always arise when economic activity increase reflects in economic growth, which is achieved by means of technologies burdening environment in a smaller extent. Negative effects arise when increased burden on environment occurs concurrently with economic growth. Moreover, it is important to consider the fact that economic growth will have a different impact on the quality of environment under the conditions of globalisation, compared to the state of selfsufficiency of a country.

- structural changes - can affect economic activities in a country. The intention of environmental policy should be an effort to create room for the transition from productions excessively burdening environment towards less burdening productions and services.

- legislation related to environment - direct and indirect tools of environmental policy can be environmentally efficient and inefficient, thus having positive or negative impact on the quality of environment.

\section{ECONOMIC GROWTH AS}

\section{A GLOBALISATION PROCESS EFFECT AND ITS ENVIRONMENTAL ASPECTS}

The views of economists on relationships between economic growth and the quality of environment are not uniform. On the other hand, there are authors like Meadows, Meadows, Randers and Behrens (1972) who express their doubts on the possibilities of long-term economic growth. On the 
other hand, there are authors who take the view that economic growth is a tool to reduce the burden on environment. Panayotou (2003) points out in this relation that the relationship between economic growth and the quality of environment does not have to be stable. However, he considers economic growth to be a basic precondition of environmental problems solution not only due to the fact that it generates an increased volume of financial resources which can be used for refinancing environmental measures, but also due to the fact that technical development enables the substitution of environmentally unsuitable technologies by cleaner ones.

In relation to examining relationships between economic growth and the quality of environment, Kuznets (1966) created a curve showing the dependence between the level of environmental pollution and the amount of income per citizen. The curve has a shape of reversed $U$. The breakpoint of Kuznets environmental curve according to Grossman and Krueger (1994) comes at the amount of income USD 8,000 per citizen of a country. However, this curve line has not been confirmed for all polluting substances. It concerns e.g. greenhouse gas production. The curve line implies that significant deterioration of the quality of environment occurs upon lower levels of economic growth, which, according to him, is a consequence of implementing outdated technologies, excessive exploitation of natural resources as well as inefficient agriculture and forestry. It is assumed at a higher level of economic growth that structural changes occur in economics; industries based on information and services are established; and environmentally suitable technologies are implemented. The amount of income of population was considered to be a significant factor having an impact on this process.

Examining the relationship between pollution and the amount of income per citizen in a long-term horizon, Harbaugh, Levinson and Wilson (2000) extended the original shape of Kuznets curve from the shape of reversed $U$ to the shape of $N$. The $N$ curve shape reflects the state when the level of pollution after income threshold value achievement decreases at first, however later, following the increase of incomes of the population, pollution repeatedly increases. In a longer time horizon, this curve line confirms the development in economically developed countries. It may be assumed that ongoing globalisation processes in other developing countries will copy this development.

It is necessary to point out in this relation that pollution reduction, which Kuznets justifies by increased income was, besides other factors, caused by the globalisation process itself, which opened room for restructuring the economics of the developed economies in the direction of the transition from environmentally demanding productions to less demanding ones and services. We would like to emphasise that this environmental burden reduction is not only a solution of global environmental problems, but also of local ones. Moreover, it is necessary to remember the fact that the restructuring process is always facilitated by stricter environmental legislation of a state, accompanied by increasing the environmental awareness of the population.

However, strict national environmental legislation can have a negative impact on the economy of a country in relation to the fact that investors, helping economic growth, can move to other countries, particularly those in which national governments "loosen" their environmental legislations in an effort to attract investors. The globalisation process thus theoretically opens room for the transfer of pollution from one country to another, while the amount of polluting substances does not change in the global system of environment. On the contrary, it can increase as a result of more significant economic growth in a host country of an investor, and subsequent income growth of its population.

Inflow of foreign investors is positively evaluated in relation to economic growth and employment in the given host country. Impact on environment is however necessary to evaluate carefully. If a host country "loosens" environmental policy tools, it cannot be a right decision. Under the precondition that environmental legislation is valid for all, i.e. no exceptions are allowed from environmental policy tools implementation, the inflow of direct foreign investments in a country can be evaluated positively, particularly when it concerns high technology enabling the given country to carry out structural changes. However, a condition is correctly valued natural resources used by the 
country, and reflection of negative externalities arising in relation to a country's production in manufacturing costs by means of the implementation of financial and economic tools (environmental taxes and charges). Only after these preconditions have been fulfilled, we can discuss a positive impact of direct foreign investments on green growth and maximisation of social welfare in the country. If it is not the case, the globalisation process carried out by means of direct foreign investments opens room for the transfer of pollution from one country to another.

\section{STRUCTURAL CHANGES AS A TOOL OF INCREASING THE QUALITY OF ENVIRONMENT}

The globalisation process by means of direct foreign investments opens room for a country to carry out structural changes. However, economic activities should focus on industries in which the country has a comparative advantage. Efforts of a host country should include the transition from heavy and processing industries towards services. In case of reductions in exigent industries regarding environmental resources, or if their growth develops slower than the GDP growth, we can speak about the arising of "free ecological effects".

The main spheres in which structural changes implementation enables an increase of ecological effects include:

- innovation of production - i.e. a decrease of the burden on environment caused by a product itself. Changes to production should result in the production of environmentally suitable products.

- change of technological procedure - during which less polluting substances are emitted or material consumption and related energy demand decrease in relation to their production.

- substitution of production inputs environmentally unsuitable production inputs are substituted by environmentally more suitable inputs.

Positive effects of structural changes can be to a certain extent eliminated by means of increasing production volumes, however only under the condition that the increased production volumes increase the pressure on environment. It does not always have to be so upon high technology implementation.

The implementation of structural changes in a country is also supported by trade liberalisation, which facilitates the purchase and subsequent usage of environmentally more suitable technologies, and it opens markets for trading with countries whose consumers prefer so called green products.

There have been several debates on the impact of trade liberalisation on the quality of environment, dealing with its positive and negative effects on environment.

Negative effects of trade liberalisation on environment are dealt with by theories "Race to Bottom" and "Poluttion Heaven" (Fortanier \& Maher, 2001). Under "Race to Bottom" theory, countries participating in international trade implement lower environmental standards in the fear of decreased competitiveness. This fear results from the fact that the implementation of strict environmental legislation will be a burden for business sector, which will result in increased manufacturing costs compared to competition obliged to observe strict environmental legislation. "Poluttion Heaven" theory points out the existence of comparative advantages which can have different negative effects on environment. Differences in the effects are conditioned by: differences in capital and labour possibilities of a country, different availability of resources, and different levels of environmental regulation.

Positive effects of trade liberalisation under "Porter Hypothesis" theory (Porter, 1990) result from the fact that multinational companies operating on a competing market always use environmentally more efficient technologies and procedures compared to the technologies and procedures implemented in a host country so far. "Gains from Trade" hypothesis (Fortanier \& Maher, 2001) results from the argument that due to trade liberalisation, the production of goods and services on the market of each state increases compared to the state presupposing the selfsufficiency of each country. Trade liberalisation is thus becoming a tool supporting the increase of environmental standards and subsequent enhancement of the quality of environment. 
Broader implementation of environmental technologies presupposes the stimulation of business sector by state focused on the participation, in a certain extent, in the effects resulting from decreased burden on environment. It is important for environmental policy in this relation to have the tools enabling a compensation of increased cost demand in the business sector (tax reliefs, depreciation, grants upon the purchase of environmentally suitable technologies etc.).

\section{GREEN GROWTH AND ENVIRONMENTAL LEGISLATION}

The achievement of behavioural changes in production and consumption decisions in the business sphere and population presupposes, besides the fulfilment of other attributes, the implementation of a broad range of environmental policy tools, which represent an essential part of each national environmental policy.

It is possible in the ongoing globalisation process to structure the environmental policy tools from various aspects. The simplest structuring is the way the given tools affect the mechanism of functioning of economics. Following the adoption of this approach, it is then possible to distinguish direct and indirect tools. Other structuring can include the division into normative financial and economic and free tools.

The implementation of direct environmental policy tools in management practice can have various forms: orders, prohibitions, restrictions of allowed pollution amounts, or even the prohibition of certain productions. However, the most frequent form is the approach based on environmental standards, while they can be standards of the quality of a selected environmental element, emission standards, technological standards as well as product standards.

A positive feature of standard-based environmental quality regulation is the fact that their implementation can ensure the fulfilment of stipulated quality of environment quite fast. $A$ negative feature of their implementation is the fact that standards are static and little stimulating. It is thus common that technical progress implementation is reflected in them with time delays. Further disadvantage of standards is that their implementation does not result in minimisation of the economic costs of an emission unit decrease.

Unlike direct tools, indirect environmental policy tools do not prescribe environmental protection, but they stimulate polluters to adopt measures reducing burden on environment. Indirect tools include payments in the form of environmental taxes, charges, contributions, compensations, emission permissions and deposit-refund systems, emissions trading as well as voluntary agreements implementation.

Indirect environmental policy tools are marketconform in their economic nature.

\subsection{Environmental Taxes as an Environmental Policy Tool}

A reason for spreading the toolkit of environmental protection towards the market was knowledge on the theory of welfare economics, under which labour, soil and capital are effectively allocated when prices of commodities equal their marginal social costs. According to this theory, those are prices regulating the allocation of resources in the direction of their most effective usage. One of the conditions of effective resources allocation is the existence of equality between private and social costs.

English economist A. C. Pigou (1932) developed the theory of welfare economics. He claimed that ineffectiveness in resources allocation originates in the existence of negative externalities, whose arising is based on the fact that environment is a public good used by economic entities regardless of the impact of their decisions on further entities, including the impact on future generations.

He comprehended negative externalities as costs imposed by one economic entity on another economic entity. He saw the elimination of ineffectiveness in the implementation of a tax on externalities, also called Pigouvian emission tax. A. C. Pigou presupposed that if emission tax equalled external costs, private costs of producers would increase at the level of social costs. Costs of the production would thus reflect social manufacturing costs and would become tools of effective resources allocation.

However, it is necessary to point out that in his reflections on emission tax, Pigou did not consider 
the existence of deformations in economics, which results in the fact that private costs differ from social costs. Such deformations are caused by e.g. economies of scale, monopoly power of the market, as well as the implementation of classic, standardly implemented taxes.

Economic science considers taxes to be a tool causing welfare losses, and in financial science, these losses are called "undue financial burden". Taxes in their economic nature disrupt conditions of effectiveness. It is therefore impossible to expect, like Pigou presupposed, that emission tax implementation will result in effective resources allocation. However, according to the theory of welfare economics, it is possible to generate a certain welfare increase by their usage due to the fact that the deformation effects of environmental taxes are lower than the deformation effects of standardly implemented taxes. Environmental taxes implementation thus applies a less distorting taxation system. The EU also supports a more extensive implementation of environmental taxes. The process of environmental taxes implementation is supported by the EU, which recommended the member states a more extensive implementation of economic tools, also including environmental taxes already in the fifth environmental action plan (1992).

There is a great amount of literature on the potential of environmental taxes to contribute to an increased efficiency of environmental policy. Several authors agree on the fact that if environmental taxes are properly designed and implemented, they can contribute positively to the minimisation of costs of environmental burden reduction, have stimulating effects in carrying out innovation processes, increase employment and, which is most important, contribute to green growth.

One of obstacles in environmental taxes implementation in taxation systems is fear in the business sector from competitiveness loss, as environmental taxes are additional tax payments generating costs of companies. The simplified consideration of competitiveness loss results from the assumption that the whole environmental tax amount will be reflected in the manufacturing costs of companies with subsequent increase of product prices, consumption reduction, production volume reduction and unemployment growth.
However, it is necessary to consider the fact that the impact of environmental tax on competitiveness is affected by several factors, including:

- First: the possibility to transfer increased costs on consumers, employees or suppliers of production inputs.

- Second: market structure, the number of market participants, the extent of regulation in economics (e.g. prices regulated by state).

- Third: the impact of international competition. The smaller and more open economics is the more restricted are possibilities of business entities to reflect increased costs in the prices of consumers and suppliers of production inputs.

- Further factors, affecting the impact of implemented tools on companies include: geographical distribution of a market, homogeneity or non-homogeneity of a product, the possibility of production inputs substitution, the ability to implement and finance new environmentally suitable technologies.

\subsection{Direct Tools and Green Growth}

The practice of environmental protection tools implementation confirms that environmental protection by means of environmental tax as an exclusive environmental policy tool is very rare. Environmental taxes are normally implemented in combination with direct environmental policy tools.

An example of using the combination of environmental taxes and direct environmental policy tools can mainly be found in Northern countries.

It is necessary to keep in mind upon the implementation of environmental tax and direct tools that the direct regulation of environmental protection presupposes that polluters are obliged to fulfil immediately the stipulated environmental standards, while environmental taxes stimulate polluters to reduce emissions where costs related to their reduction are lower than the environmental tax amount a polluter would be obliged to pay. It is necessary to emphasise in this relation that the stimulating impulse of environmental tax is necessary to evaluate over time in order not to 
prevent the flexibility of polluters in looking for cost-effective possibilities of reducing the burden on environment.

\subsection{Environmental Tax and Tradable Permissions}

Trading with emission permissions is a modified form of direct environmental protection tools. The idea characterising the nature of trading with emission rights is an effort to create markets for environmental resources.

The main reason of the situation when such markets are not created spontaneously is generally considered absence of property rights on environmental resources.

Therefore, efforts to solve the problem reflected in the creation of property rights on emissions. The creation of such rights proceeds as follows: the regulation centre responsible for the quality of environment stipulates the amount of emissions of harmful substances which can be released in the system of a selected environment element for a certain period without exceeding the respective imission standard. Subsequently, maximum allowed emission volume is divided among individual polluters.

Polluter thus gets the emission right. In case emissions in their company have been reduced under the stipulated level, they can emit their right, sell "the remaining emissions", or if they emit more emissions than their allocated emission right, they have to buy the right to emit them.

The functioning of the market with emission rights is affected by several factors, including:

- the existence or non-existence of environmental technologies enabling emission reduction,

- active market with several buyers and sellers enabling transparent generation of emission prices,

- the ability of offices responsible for pollution control to monitor emissions and carry out their control,

- market rules which need to be simple and transparent and have to result in low transaction costs.

The aforementioned factors have a significant impact on economic effectiveness as well as environmental efficiency of trading with emission permissions. Under the precondition that factors affecting the market functioning have been fulfilled, trading permissions usage enables:

- to balance costs of reducing the burden on environment,

- to stimulate technological changes oriented on the burden reduction,

- to provide a high level of environmental safety by means of stipulating a maximum limit of environmental pollution,

- flexibility in generating distribution and redistribution effects.

Arguments justifying the parallel implementation of environmental tax and tradable permissions include the fact that their interaction creates a tool for reducing uncertainty upon emission reduction at minimum costs. Both tools increase the flexibility of environmental policy toolkit, however with different environmental efficiency and economic effects distribution. The enforcement of environmental taxes in combination with the tradable permissions system has spread in relation to free allocation of emission permissions.

\subsection{Environmental Taxes and Voluntary Tools}

Over the last years, so called soft law, including so called voluntary tools of environmental behaviour, has been implemented in environmental protection besides economic tools.

We can say that it is a reflexive regulation related to the implementation of "self-reflexive" approaches of companies considering the impact of their activities on environment. Such companies - polluters are not an object of regulation by institutions responsible for the quality of environment, but they have become a part of the regulation process on the grounds of their own decision. Such tools include EMS and EMAS environmental management systems as well as labelling of environmentally suitable products and voluntary agreements.

EMS system according to ISO 14001 is a globally accepted environmental management standard. The system of managing companies and audit from the viewpoint of environmental protection EMAS was created from the initiative of the 
European Union and is most frequently implemented within the European area. EMAS system represents a higher level of environmental management than ISO 14001 standard. However, the system follows the standard and arises from it. Following the implementation of voluntary agreements, some industries can be exempted from environmental tax payment, or they pay lower taxes compared to other sectors under the condition that they have voluntarily decided to carry out measures to reduce the burden on environment.

Advantages resulting from voluntary agreements implementation are important for business sector due to the fact that the "agreement" creates room for a greater flexibility upon the fulfilment of environmental objectives compared to the implementation of other environmental policy tools. Public sector gives up the income from environmental payments collection and subsequent possibility of their usage for the benefit of environmental protection upon voluntary agreements implementation.

Views on the suitability of implementing a toolkit which would efficiently affect the burden reduction and at the same time eliminate the possibility of environmental risks creation vary not only in theory but also in the management sphere itself. In spite of exceptions, business sphere opposes the process of making the implemented environmental protection toolkit stricter. Governments themselves are concerned in relation to a stricter toolkit, particularly when they would like to be pioneers in the greening of economy. A certain solution is a common procedure of all countries upon the implementation of stricter environmental legislation.

Without the implementation of harmonised legislation on environmental protection, the globalisation process places less developed and developing countries in an "environmental trap" and at the same it, it creates room for the transfer of pollution from developed to less developed countries. The creation of mechanisms of environmental protection transnationally, which would be valid for all polluters in each country, can be a significant shift in solving this issue (Kubicova, 2009). Cooperation of sovereign states in the sphere of taxes and international taxation is a new phase, which has significantly shifted the solution of environmental problems, too. Individual countries, as the addressees of transnational environmental regulation implementation, should be obliged to bear responsibility for environmental protection at the given territory and for preventing the arising of environmental risks. It is always necessary to evaluate positively the initiative of countries upon adopting their own national legislations tightening the transnational regulation. The first approaches towards the creation of transnational mechanisms focused on the prevention of environmental risks occurrence can be found in interstate agreements, which include Montreal protocol, Kyoto protocol, tax on energy adopted in the EU, etc.

Political willingness of governments to cooperate upon environmental protection presupposes taking responsibility for further development of the wold and for the right for clean environment for all. International agreements upon solving global problems have to create a basis for effective cooperation in the sphere of environment.

\section{CONCLUSION}

The examination of factors affecting green growth is very complex due to the fact that the globalisation process generates positive as well as negative effects in relation to environment.

An increase of positive effects of the globalisation process in relation to ensuring green growth presupposes:

- the ensuring of closer interrelatedness of economic, financial and environmental policies so that effects having negative environmental impact are wilfully prevented,

- the implementation of a more efficient stimulating system of environmental policy tools, by means of which it would be possible to approach the internalisation of negative externalities more thoroughly,

- the enhancement of environmental policy efficiency by means of implementing a broad range of voluntary tools,

- the reduction of natural resources devastation presupposes a purposeful distribution of financial resources for the benefit of population living at the edge of society.

Reflection of the aforementioned measure in environmental policy in an effort to mitigate 
negative effects of the globalisation process on increasing their stimulating function and environment presupposes the existence of environmental efficiency.

efficient environmental policy tools aimed at

\section{WORKS CITED}

European Commission. (2010). Communication from the Commission - Europe 2020: A strategy for smart, sustainable and inclusive growth. COM (2010) 2020 final. Brussels: European Commission. Retrieved from http://ec.europa.eu/research/era/docs/en/investing-in-researcheuropean-commission-europe-2020-2010.pdf

Fortanier, F., \& Maher, M. (2001). Foreign Direct Investment and Sustainable Development. OECD Global Forum on International Investment (pp. 1-12). Mexico City: OECD. Retrieved from http://www.oecd.org/dataoecd/54/19/2408079.pdf

Grossman, G. M., \& Krueger, A. B. (1994). Economic growth and the environment. Quarterly Journal of Economics, 110(2), 357-377. Retrieved from http://www.nber.org/papers/w4634

Harbaugh, W., Levinson, A., \& Wilson, D. (2000, 05). Reexamining the Empirical Evidence for an Environmental Kuznets Curve. Retrieved from NATIONAL BUREAU OF ECONOMIC RESEARCH: http://www.nber.org/papers/w7711.pdf

Kubicova, J. (2009). International Taxation. Economist.

Kuznets, S. (1966). Modern Economic Growth: Rate, Structure and Spread. New Haven, Conn.: Yale University Press.

Meadows, D. H., Meadows, D. L., Randers, J., \& Behrens, W. W. (1972). The Limits to Growth. New York: Universe Books. Retrieved from http://www.donellameadows.org/wpcontent/userfiles/Limits-to-Growth-digital-scan-version.pdf

Panayotou, T. (2003). Economic Growth and The Environment. Economic Survey of Europe. United Nations, Secretariat of the Economic Commission for Europe. Geneve: United Nations. Retrieved from http://www.unece.org/ead/pub/032/032_c2.pdf; http://www.unece.org/fileadmin/DAM/ead/sem/sem2003/papers/panayotou.pdf

Pigou, A. C. (1932). The Economics of Welfare (4th ed.). Cambridge: Macmillan and Co.

Porter, M. (1990). Competitive advantage of nations. New York: Free Press, MacMillan.

Received for publication: $\quad 26.03 .2014$

Revision received: $\quad 12.05 .2014$

Accepted for publication: $\quad 23.06 .2014$

\section{How to cite this article?}

Style - APA Sixth Edition

Romančikova, E. (2014, 07 15). Green growth and possibilities of its ensuring. (Z. Čekerevac, Ed.) MEST Journal, 2(2), 204-213. doi:10.12709/mest.02.02.02.21

Style - Chicago Fifteenth Edition:

Romančikova, Eva. 2014. "Green growth and possibilities of its ensuring." Edited by Zoran Čekerevac. MEST Journal (MESTE) 2 (2): 204-213. doi:10.12709/mest.02.02.02.21. 
Style - GOST Name Sort:

Romančikova Eva Green growth and possibilities of its ensuring [Journal] // MEST Journal / ed. Čekerevac Zoran. - Belgrade : MESTE, 07 15, 2014. - 2 : Vol. 2. - pp. 204-213.

Style - Harvard Anglia:

Romančikova, E., 2014. Green growth and possibilities of its ensuring. MEST Journal, 15 07, 2(2), pp. 204-213.

Style - ISO 690 Numerical Reference:

Green growth and possibilities of its ensuring. Romančikova, Eva. [ed.] Zoran Čekerevac. 2, Belgrade : MESTE, 07 15, 2014, MEST Journal, Vol. 2, pp. 204-213. 